\title{
Rupture of a rudimentary horn at 16 weeks of gestation
}

\author{
Onaltıncı gebelik haftasında rudimenter horn rüptürü \\ İlhan Bahri Delibaş ${ }^{1}$, Ünal İsaoğlư ${ }^{1}$, Mehmet Yılmaz ${ }^{1}$, Sedat Kadanalı ${ }^{2}$ \\ ${ }^{1}$ Nenehatun Obstetrics and Gynecology Hospital, Erzurum, Turkey \\ ${ }^{2}$ Department of Obstetrics and Gynecology, Ataturk University Aziziye Research Hospital, Erzurum, Turkey
}

\begin{abstract}
A patient with acute abdomen at 16th week of gestation underwent an emergency laparotomy. At laparotomy two litres of fibrinated and free blood and a dead fetus with placenta was detected intraabdominally. The right ovary and tube was normal and the uterus was normal in size. There was a ruptured and actively bleeding uterine horn on the left side of the uterus. The ruptured uterine horn was excised with the left tube by preserving the left ovary. The patient recovered without any complications. J Clin Exp Invest 2011;2(2):219-21
\end{abstract}

Key words: Rudimentary horn, pregnancy, rupture

\section{INTRODUCTION}

Congenital uterine anomalies have been classified by the American Fertility Society. ${ }^{1}$ The prevalence of uterine anomalies in general population is $0.5 \%{ }^{2}$ In a retrospective study conducted in our country, prevalence of uterine rupture in non-scarred uteri is reported as 1 per 2119 deliveries. ${ }^{3}$ Unicornuate uterus is the second rarest seen Mullerian anomaly after uterus didelphys comprising $10 \%$ of all uterine anomalies. ${ }^{4}$ It is estimated to be due to failure of migration of one of the Mullerian ducts to its normal destination. ASRM classified this anomaly as unicornuate uterus with communicating or noncommunicating horn, unicornuate uterus with no cavity and unicornuate uterus with no horn. Ninety percent of rudimentary uterine horns are non-communicating. ${ }^{5}$

\section{CASE}

A 27 years-old multigravida who had a complaint of abdominal pain for 24 hours was referred to our clinic from the emergency service of a local mater-

\section{ÖZET}

Onaltıncı gebelik haftasında akut batın tablosu ile gelen hasta acil laparotomiye alındı. Laparotomide intraabdominal iki litre fibrine ve defibrine kan ve ölü bir fetus ile birlikte plasentası tesbit edildi. Sağ over ve tüp normal görünümde ve uterus normal boyutlardaydı. Uterusun solunda rupture ve aktif kanamalı uterin horn gözlendi. Rupture uterin horn sol over korunarak sol tüp ile birlikte eksize edildi. Hasta herhangi bir komplikasyon gelişmeden taburcu edildi. Klin Deney Ar Derg 2011;2(2):219-21

Anahtar kelimeler: Rudimenter horn, gebelik, yırtılma

nity hospital with the general diagnosis of acute abdomen. She had a history of a caesarean delivery at term 3 years ago and a preterm vaginal delivery at 32 weeks 1 year ago. She attended no routine visits in that pregnancy.

On admission she was somnolent and her blood pressure was 90/60 $\mathrm{mmHg}$ and her pulse was 96 bpm. On abdominal examination she had severe abdominal tenderness and rebound on the left lower quadrant. Vaginal examination revealed severe cervical motion tenderness. No vaginal bleeding or cervical dilatation was detected.

Her laboratory values were as follows: hemoglobin $7.1 \mathrm{~g} / \mathrm{dl}$, hematocrit $21 \%$, White blood cell count 18200 and platelets $322 \times 109 / \mathrm{L}$. Her coagulation profile was normal.

On abdominal ultrasound (USG) there was extensive abdominal fluid, a normal-sized uterus with $16 \mathrm{~mm}$ endometrial thickness and a neighbouring extrauterine 16 week-fetus with no cardiac activity.

Intravenous fluid resucitation was commenced. Twenty minutes after her admission she was trans- 
ferred to operation room for exploratory laparotomy with the suspected diagnosis of uterine rupture.

At laparotomy two litres of fibrinated and free blood and a dead fetus with placenta was detected intraabdominally. The right ovary and tube was normal and the uterus was normal in size. There was a ruptured and actively bleeding uterine horn on the left side of the uterus. The left tube was short and connected to the uterine horn. There was no connection detected between the horn and the main uterine cavity. The ruptured uterine horn was excised with the left tube by preserving the left ovary. The patient was given 3 units of packed cells and two units of fresh frozen plasma.

The patient recovered without any complications. The histopathology report verified the diagnosis of pregnancy and rupture of the uterine rudimentary horn.

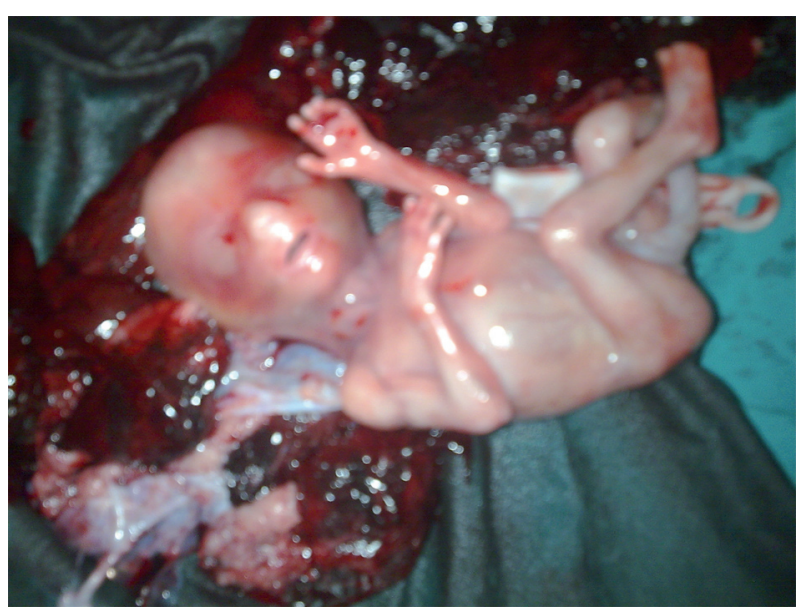

Figure 1. Intra-operative photograph showing the posterior view of the uterus with ruptured rudimentary horn

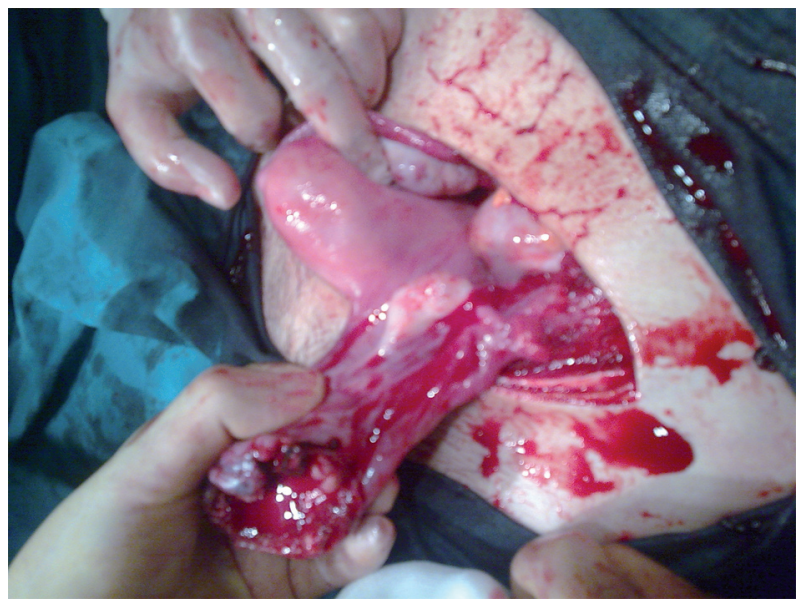

Figure 2. Fetus and Placenta

\section{DISCUSSION}

Congenital uterine anomalies have been classified by the American Fertility Society. ${ }^{1}$ The prevalence of uterine anomalies in general population is $0.5 \%{ }^{2}$ In a retrospective study conducted in our country, prevalence of uterine rupture in non-scarred uteri is reported as 1 per 2119 deliveries. $^{3}$ Unicornuate uterus is the second rarest seen Mullerian anomaly after uterus didelphys comprising $10 \%$ of all uterine anomalies. ${ }^{4}$ It is estimated to be due to failure of migration of one of the Mullerian ducts to its normal destination. ASRM classified this anomaly as unicornuate uterus with communicating or noncommunicating horn, unicornuate uterus with no cavity and unicornuate uterus with no horn. Ninety percent of rudimentary uterine horns are non-communicating. ${ }^{5}$

Ultrasonography may be helpful in diagnosing such anomalies before rupture. It is helpful in decreasing the morbidity and mortality associated with rapid and massive haemoperitoneum due to rupture.

Pregnancy in a non-communicating rudimentary horn occurs through transperitoneal migration of sperm or fertilized ovum. ${ }^{6}$ It is associated with spontaneous abortion, preterm labor, intrauterine growth retardation, intraabdominal haemorrhage and uterine rupture. ${ }^{7}$ Rupture is reported to occur usually between 10-15 weeks. ${ }^{8}$ Time of rupture depends on the structure of the rudimentary horn. Since myometrium is very thin and there is a high risk of uterine rupture, in rudimentary horn pregnancy prophylactic removal is recommended. To reduce the maternal mortality rate, removal of rudimentary horn gestation is suggested in the first trimester before imminent rupture. ${ }^{9}$

In our case, rupture of the rudimentary horn occured at $16^{\text {th }}$ week of gestation. Ambulatory operation and intensive care was life saving. Urinary system malformations may also accompany Mullerian anomalies in $38 \%$ of the cases. ${ }^{10}$ In this case there was no urinary system anomaly in postoperative intravenous pyelography.

\section{REFERENCES}

1. The American Fertility Society. The American Fertility Society classifications of adnexal adhesions, distal tubal occlusion, tubal occlusion secondary to tubal ligation, tubal 
pregnancies, müllerian anomalies and intrauterine adhesions. Fertil Steril 1988;49 (6):944-55.

2. Nahum GG. Uterine anomalies. How common are they, and what is their distribution among subtypes? J Reprod Med 1998;43 (10):877-87.

3. Evsen M, Sak M.E., Bozkurt Y, Kapan M, Bakır C. Uterine rupture: Regional incidence, causes and treatment. Dicle Tip Dergisi 2008; 35(4):260-4.

4. Speroff L, Fritz M.A.Clinical Gynecologic Endocrinology and Infertility. $7^{\text {th }}$ edn. Philadelphia: Lippincott Williams \& Wilkins, 2005:133.

5. Goel P, Aggarwal A, Devi K, Takkar N, Saha PK, Huria A. Unicornuate uterus with non-communicating rudimentary horn. Different clinical presentations. J Obstet Gynecol India 2005;55 (2):155-8.
6. Panayotidis C, Abdel-Fattah M, Leggott M. Rupture of rudimentary uterine horn of a unicornuate uterus at 15 weeks' gestation. J Obstet Gynaecol 2004; 24 (3):323-4.

7. Jin Woo Shin, Hai Joong Kim. Case of live birth in a noncommunicating rudimentary horn pregnancy. J Obstet Gynaecol Res. 2005,31(4):329-31.

8. O'Leary J. L. and O'Leary J. A Rudimentary horn pregnancy. Obstet Gynecol 1963; 22(3): 371-5.

9. Kriplani A, Relan S, Mittal S, Buckshee K. Pre-rupture diagnosis and management of rudimentary horn pregnancy in the first trimester. Eur J Obstet Gynecol Reprod Biol 1995;58 (2):203-5.

10. Heinonen PK. Unicornuate uterus and rudimentary horn. Fertil Steril 1997;68 (2):224-30. 